\title{
Bioequivalence trial of diclofenac sodium tablets: effects of Eudragit and tablet preparation, formulation characteriza- tion, release profiles, and bioavailability measurements
}

\section{Ispitivanje bioekvivalencije Diklofenaka: efekti Eudragita, pripreme tableta i karakteristika formulacija na profile oslobađanja i mjere bioraspoloživosti}

Sanja Kecman, ${ }^{1}$ Milan Jokanovic ${ }^{2}$

1. Hemofarm d.o.o, a Member of Stada Group, Banja Luka, The Republic of Srpska, Bosnia and Herzegovina

2. Department of Pharmacy, Faculty of Medicine, University of Niš, Niš, Serbia

RECEIVED 25.01.2018.

ACCEPTED 02.03.2018.

\section{ABSTRACT}

Objective. The study was aimed to evaluate the effects of changing excipients, including type of Eudragit polymer, on release and absorption profiles in vitro and in vivo, of tablets containing the antiinflammatory drug, diclofenac sodium.

Methods. Formulation 1 consisted of diclofenac sodium tablets containing Eudragit L30, and Formulation 2 consisted of diclofenac sodium tablets containing Eudragit L100, and both formulations contained different excipients. Tablets were assessed, in vitro, for weight, hardness, diameter, thickness, mass uniformity, disintegration and dissolution profiles and drug content. Tablets were also assessed in vivo by gavage in healthy rabbits and assessing diclofenac sodium plasma concentrations and pharmacokinetic parameters.

Results. Results showed that in vitro analyses demonstrated non-equivalence while in vivo analyses demonstrated equivalence. This suggests that although different types of Eudragit and excipients modulated the in vitro dissolution and release profiles of diclofenac sodium, in vivo absorption in rabbits remained similar representing bioequivalence.

Conclusion. It is needed to conduct evaluations of bioequivalence of diclofenac sodium oral preparations at both in vitro and in vivo conditions.

Key words: diclofenac; drug compounding; drug liberation; pharmacokinetics; therapeutic equivalency.

\author{
Sanja Kecman, ${ }^{1}$ Milan Jokanović ${ }^{2}$ \\ 1. Hemofarm d.o.o, član STADA grupe, Banja Luka, Republika Srpska, Bosna \\ Hercegovina \\ 2. Institut za farmaciju, Medicinski fakultet, Univerzitet u Nišu, Niš, Srbija
}

PRIMLJEN 25.1.2018.

PRIHVAĆEN 2.3.2018.

\section{APSTRAKT}

Cilj. Studija je imala za cilj procijeniti učinke promjena ekscipijenata, uključujući tip Eudragit polimera, na profil otpuštanja i apsorpcije in vitro $\mathrm{i}$ in vivo, tableta koje sadrže protuupalni lijek, diklofenak.

Metode. Formulacija 1 sastojala se od diklofenaknih tableta koje sadrže Eudragit L30, a Formulacija 2 sastojala se od tableta diklofenaka koje sadrže Eudragit L100, a obje formulacije sadržavale su različite ekscipijente. Tablete su ispitivane in vitro prema težini, tvrdoći, dijametru, uniformnosti mase, vremenu razlaganja, disolucionim profilima i sadržaju lijeka. U drugom dijelu istraživanja, nakon oralnog davanja diklofenaka zečevima, ispitivani su koncentracija lijeka u plazmi i farmakokinetički parametri.

Rezultati. Istraživanje pokazuje da, i pored razlike u profilima oslobađanja diklofenaka in vitro, postoji bioekvivalentnost ispitivanih formulacija. Navedeno ukazuje da, iako su različite vrste Eudragita i ekscipijensa uticale na in vitro rastvaranje i profil otpuštanja diklofenaka, in vivo apsorpcija kod zečeva ostala je slična i potvrđuje bioekvivalentnost

Zaključak. Evaluacija bioekvivalencije oralnih preparata diklofenak natrijuma treba da se sprovodi i $u$ in vitro i $u$ in vivo uslovima.

Ključne riječi: diklofenak; izdrada lekova; oslobadjanje lekova; farmakokinetika; terapijska ekvivalencija. 


\section{INTRODUCTION}

Determining a correlation between in vitro physical and release properties, and in vivo bioavailability profile of a drug has widely been presented in the bibliography studeis. ${ }^{1,2}$ Assuming correlation, it is possible to use in vitro data to predict the behavior of the drug in the in vivo conditions. This is anticipated to significantly lower need for expensive bioequivalence evaluations in humans. ${ }^{3}$ In vitro drug disintegration and dissolution profiles are likely to become different than in vivo profiles, but the difference may not be signfificant. The process of in vivo gut absorption is far more complex, more variable and less predictable than in vitro. ${ }^{4}$

Dissolution tests are well-established techniques to best predict drug absorption and bioavailability. Correlation of dissolution tests with the in vivo absorption are more complex since many factors can affect findings. These factors include age, gender, concomitant food intake, health status, genetic predisposition and physical activity. Bioequivalence studies on optimal number of subjects are crucial for the valid conclusions. ${ }^{5,6}$ In practice, dissolution profiles in vitro can benefit from utilization of similarity factors (f2). ${ }^{7}$ Compared products are considered equivalent if the similarity factor is higher than $50 \%$. Dissolution profile of a drug, besides methods used in the dissolution test, equipment and dissolving media, is at the greatest extent influenced by factors of tablet formulation. The amount and the correlation of binders and disintegrants as excipients, the coating method and choice of coating material, as well as the hardness of tablets are the key parameters of tablet formulation.

Many authors have evaluated the influence of different formulations on physical, chemical and pharmacokinetic parameters of drugs and came to the conclusion that in vitro/in vivo correlation exists, ${ }^{8-10}$ although other authors have claimed that such studies are not warranted. ${ }^{11,12}$ Accordingly, the aim of this study was to evaluate the correlation.

The study aimed to assess the correlation and effects of changing excipients including type of polymer, on release and absorption profiles in vitro and in vivo, of tablets containing the non-steroidal antiinflammatory drug, diclofenac sodium.

\section{MATERIALS AND METHODS}

All substances used in this study were obtained from Hemofarm AD, a Member of Stada Group. Two different formulations of diclofenac sodium, were used. The method used in preparation of both formulations of diclofenac sodium was wet granulation, with different coating procedures of the tablet core. By comparing the physical and chemical parameters of the tested formulations in vitro and pharmacokinetic parameters in vivo, it was determined whether they are equivalent or not.

Tablet formulation 1. After granulation of raw material/ingredients (diclofenac sodium, lactose monohydrate, maize starch, silica dioxide), microcrystalline cellulose and magnesium stearate were added. The prepared mix was tableted, after which the coating of the tablet core was done using layer of Eudragit L30 D55 and layer of hydroxypropylmethylcellulose (HPMC).

Tablet formulation 2. After granulation of ingredients (diclofenac sodium, maize starch, sodium lauryl sulfate, sodium carboxymethyl starch, silica dioxide, lactose monohydrate, sodium carboxymethyl starch, magnesium stearate were added and after mixing, the next step was tableting. Coating of the tablet core was done using layer of Eudragit L100 D55.

\section{Evaluations in vitro}

It is necessary to have a quantitative check of tablets' physical and chemical parameters, to have them shaped during the manufaturing process and to have their quality monitored in the final control check. In vitro evaluations of the final products are related to the evaluation of the parameters of the in-process control, pharmaceutical and chemical parameters of the film-coated tablets of both formulations being tested, analysis of the influence of formulation factors and different technological procedures of manufacturing on the pharmaceutical parameters, analysis of equivalence of dissolution profiles of the tested formulations and determining the similarity factors. Validation of tests on assay of diclofenac sodium and dissolution have been done according to ICH Guideline. ${ }^{13-15}$

Evaluation of in-process parameters, pharmaceutical and chemical parameters and dissolution profiles

Analysis of in-process parameters included measurement of tablets core weight (mg) using the method $\mathrm{Ph}$. Eur.2.9.5 and hardness $(\mathrm{N})$ using the method $\mathrm{Ph}$. Eur.2.9.8. ${ }^{16}$ Analysis of final products related to the following parameters: thickness and diameter of the film-coated tablets, measured by a micrometer. The average weight and uniformity of film-coated tablets were analysed using 
Ph. Eur.2.9.5., while disintergration of film-coated tablets was done using Ph.Eur.2.9.1. ${ }^{16}$ The content of diclofenac sodium in the tested formulations was determined by using the method of high pressure liquid chromatography (HPLC) on HPLC Agilent 1100 (column: LiChrospher 60 RP select B $(5 \mu \mathrm{m}), 250 \mathrm{~mm} \times 4 \mathrm{~mm})$. The mixture of solution $0.1 \% \mathrm{~m} / \mathrm{v}$ of phosphoric acid $85 \%$ was used as a mobile phase: $0.16 \% \mathrm{~m} / \mathrm{v}$, sodium dihydrophosphate (1:1), titrated to $\mathrm{pH}$ 2.5: methanol $(340 \mathrm{ml}: 660 \mathrm{ml})$, flow rate: $1.0 \mathrm{ml} /$ min, temperature: $25^{\circ} \mathrm{C}$, detection: UV $280 \mathrm{~nm}$, injection volume: $20 \mu \mathrm{l}$. Referent solution was prepared by measurement of $25 \mathrm{mg}$ diclofenac sodium as reference substance and its disintegration in $25 \mathrm{ml}$ in the mobile phase. A sample of $5 \mathrm{ml}$ of the obtained solution was diluted with $100 \mathrm{ml}$ of the mobile phase. The tested solutions were prepared by measurement of 5 film-coated tablets, dissolved with $350 \mathrm{ml}$ of the diluent. The obtained solution was completed with the mobile phase up to $500 \mathrm{ml}$, and after a centrifuge the supernatant was filtrated through a membrane filter $0.45 \mu \mathrm{m}$. Estimation and calculation of the diclofenac sodium content in the tested formulations was performed based on the external standard, with the use of peak area. The value of the content of diclofenac sodium in the tested film-coated tablets was calculated. Validation characteristics: specificity, accuracy, precision, linearity, range and reproducibility have been tested.

Defining dissolution profile of both tested formulations was performed with 12 tablets each. Tests were handled by using the paddle method (Method II, Paddle, Ph.Eur.) 17 on spectrophotometer Agilent 8453, in phosphate buffer $\mathrm{Ph} 6.8$ volume $900 \mathrm{ml}$, at the rotation speed of $100 \mathrm{rpm}$ and the temperature of $37^{\circ} \mathrm{C} \pm 0.5$. Diclofenac sodium was used as the reference standard. The reference solution was prepared by dissolving $55 \mathrm{mg}$ of referent substance in $100 \mathrm{ml}$ of diluent, after that $5 \mathrm{ml}$ of the obtained solution was completed with the $50 \mathrm{ml}$ of diluent. The tested solutions, prepared in the same way, before use, were filtrated through the membrane filter $0.45 \mu \mathrm{m}$. Measurements were done by means of the spectrophotometric method at $276 \mathrm{~nm}$. The average values of dissolution in all samples were obtained according to the calculation software and expressed as a percentage of released active substance in defined time intervals.

Validation characteristics: specificity, accuracy, repeatability, precision, linearity, range, robustness and solution stability have been tested.

Obtained values were used for calculating similarity factors by formula:?

$$
\mathrm{f} 2=50 \mathrm{x} \log \left[\left[1+(1 / \mathrm{n}) \sum \mathrm{t}=1 \mathrm{n}(\mathrm{Rt}-\mathrm{Tt}) 2\right]-0,5 \times 100\right]
$$

Similarity factor is the logarithmic reciprocal square root transformation of a sum of squared error and is a measurement of the similarity between the two curves, expressed in percentages, where: $\mathrm{n}$ - number of samples, Rt dissolution value of formulation 1 at time $\mathrm{t}$, $\mathrm{Tt}$ dissolution value formulation 2 at time $t$.

The measurement of diclofenac sodium concentrations in rabbit plasma

All experimental procedures in animals were conducted according to the Guidelines on Human Care of Experimental Animals and approved by the institutional Ethical Committee of the Medical Faculty in Banja Luka. The concentrations of diclofenac sodium in rabbit plasma at defined time intervals was performed by the HPLC method. Hewlett Packard 1200 with binary pump and UV detection $254 \mathrm{~nm}$ (columnZorbax SB-C18, $250 \mathrm{x}$ $4.6 \mathrm{~mm}, 5 \mu \mathrm{m}$ ) was an apparatus used for HPLC analysis. As a mobile phase the used buffer was $\mathrm{pH} 2.5$ (solutions $0.01 \mathrm{M}$ phosphoric acid and 0.01 M sodium dihydrophosphate phosphate mixed in a ratio 50:50 and $\mathrm{pH}$ was set by adding concentrated phosphoric acid with mixing on $\mathrm{pH}$-meter, flow rate $1 \mathrm{ml} / \mathrm{min}$, temperature $25^{\circ} \mathrm{C}$, injection volume $100 \mu \mathrm{L}$. The solution of the mobile phase and diluent (methanol p.a.) were mixed in 30:70 ratio (300 $\mathrm{ml}+700$ $\mathrm{ml}$ ), filtered and degased before usage. Referent solution was prepared by measurement of $10 \mathrm{mg}$ of diclofenac sodium BP-USP on analytical scale and by adding $10 \mathrm{ml}$ of mobile phase to obtain $1 \mathrm{mg} / \mathrm{ml}$ concentration. In order to get concentration of $0.01 \mathrm{mg} / \mathrm{ml}, 1 \mathrm{ml}$ was taken from that solution and dissolved in $100 \mathrm{ml}$ of mobile phase. The tested samples were prepared by the measurement of 0.5 $\mathrm{ml}$ plasma where $1 \mathrm{ml}$ mixture of hexane:isopropanol (90:10) was added. The given sample was, after mixing in ultrasonic mixer, moved to ultrasonic bath. After an hour spent in the ultrasonic bath, they were taken out and centrifuged at $12000 \mathrm{rpm}$. The supernatant was extracted and steamed to dry in vacuum drying and then the gained residue was dissolved in the mobile phase and injected in volume of $100 \mu \mathrm{L}$. Concentrations of the tested samples were obtained based on the area below peak curve of standard solutions and the tested samples. The analytical method is linear in the range from 0.03997 $\mathrm{mg} / \mathrm{ml}$ to $0.06037 \mathrm{mg} / \mathrm{ml}$ with regard to the correlation coefficient $r=0.999$.

Administration of diclofenac sodium to rabbits and determination of pharmacokinetic parameters in vivo.

In vivo evaluations were related to the testing of pharmacokinetic parameters: AUC0-t, Cmax, Tmax, T1/2 in order to determine bioequivalence of the tested formulations. Evaluations of pharmacokinetic parameters and bioequivalence were performed on six rabbits, weighing 
3.35- $5.20 \mathrm{~kg}$. Plasma concentrations of diclofenac sodium in the animals were determined in the defined time intervals after formulation 1 and formulation 2 single dose administration $(50 \mathrm{mg})$, respectively. The rabbits were administered the drug doses by gavage. In the defined time intervals one $\mathrm{ml}$ of blood was taken from the rabbit's ear vein. The blood sample were placed in test tubes containing diluted heparin drop, mixed up and centrifuged at $4000 \mathrm{rpm}$ to separate $0.5 \mathrm{~mL}$ of plasma.

Both diclofenac sodium formulations were administered in crossover manner to the same animal to avoid individual variations between animals. The period between administration of doses (washout period) was fourteen days which was necessary for the first dose of the tablet formulation of diclofenac sodium to be completely eliminated. Comparison of the pharmacokinetic parameters was performed for every individual animal, as well as for the entire group.

\section{Statistical data analysis}

Statistical analysis of the in-process communication parameters (IPC) and plasma concentration of diclofenac sodium in rabbits as well as pharmacokinetic parameters were expressed using average values and standard deviations. ${ }^{17}$ The results were processed by t-test for IPC parameters and analysis of variance (ANOVA) for the parameters obtained from diclofenac sodium plasma concentrations. Statistical analysis was performed by MATLAB version $2016 a$.

\section{RESULTS}

\section{In-process parameters of tested formulations}

Statistical analysis of IPC parameters show that there was a significant difference in average weight of tablet cores and their hardness (Table 1).

Table 1. Comparative presentation of IPC parameters of tablet cores formulations 1 and 2 .

\begin{tabular}{|l|l|c|c|l|}
\hline Test & Method & Formulation 1 & Formulation 2 & $p$ values \\
\hline $\begin{array}{l}\text { Average weight } \\
10 \text { cores }(\mathrm{g})\end{array}$ & Ph.Eur.2.9.5. & $\begin{array}{c}0.180 \\
(0.176-0.185)\end{array}$ & $\begin{array}{c}0.200 \\
(0.196-0.204)\end{array}$ & $\mathrm{p}<0.001$ \\
\hline Hardness $(\mathrm{N})$ & Ph.Eur.2.9.5. & $79(66-90)$ & $55(41-60)$ & $\mathrm{p}<0.001$ \\
\hline
\end{tabular}

There is sufficient evidence not to accept the hypothesis that masses of the formulations 1 and 2 were the same (p-value $<0.001$ ). Formulation F1 has significantly smaller mass than F2. There is sufficient evidence to reject the hypothesis that the hardness of the formulations 1 and 2 are the same ( $\mathrm{p}$-value $<0.001)$. Formulation F1 has significantly higher hardness than F2.

\section{Analysis of the final product}

The final analysis was performed after the coating phase of tablet cores (Table 2). The analysis showed that in tablet formulations there were no significant differences in diameter, thickness and mass uniformity, while the results of average weight of film-coated tablets and time of disintegration show significant difference. Content of diclofenac sodium was in the specification range.

Table 2. Comparative analysis of final product results.

\begin{tabular}{|l|c|c|c|c|}
\hline Test & Method & Formulation 1 & Formulation 2 & p values \\
\hline Diameter (mm) & Measuring & 8 & 8.10 & NS \\
\hline Thickness (mm) & Measuring & 4.1 & 4.21 & NS \\
\hline $\begin{array}{l}\text { Average weight } \\
\text { (mg) }\end{array}$ & Ph. Eur. 2.9.5 & 197.2 & 215.24 & $\begin{array}{c}\mathrm{p}< \\
0.001\end{array}$ \\
\hline Mass uniformity & Ph. Eur. 2.9.5 & $20 / 20 \pm 7.5 \%$ & $20 / 20 \pm 7.5 \%$ & $\mathrm{NS}$ \\
\hline $\begin{array}{l}\text { Disintegration } \\
\text { (sec) }\end{array}$ & Ph. Eur. 2.9.1 & 968 & 705 & $\begin{array}{c}\mathrm{p}< \\
0.001\end{array}$ \\
\hline $\begin{array}{l}\text { Content (mg/ } \\
\text { tbl): Diclofenac } \\
\text { sodium }\end{array}$ & HPLC & 50.3 & 49.8 & $\mathrm{NS}$ \\
\hline
\end{tabular}

Dissolution profiles of tested formulations and similarity factors

Figure 1 shows dissolution profiles and points out the significant similarities, but also differences in the disintegration rate of tablets from the both formulations. During the first 10 minutes about $64 \%$ of tablets dissolved in the formulation 2 , while this percentage was only $10 \%$ in the formulation 1 . In the period between 10 to 20 minutes about $25 \%$ of tablets dissolved in the formulation 2 while that percentage was about $55 \%$ in the formulation 1 . The tablets from both formulations were completely dissolved after 30 minutes. The value of the calculated similarity factor in in vitro conditions $\mathrm{f} 2=23.83$ shows that the dissolution profiles of the tested formulations were not equivalent.

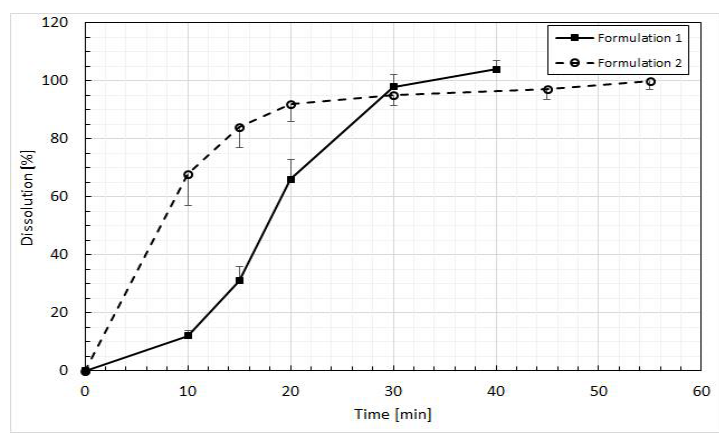

Figure 1. Average values of dissolution of tested samples $(n=12)$ at defined time intervals. 


\section{Pharmacokinetic parameters}

Analysis of pharmacokinetic parameters showed that there were significant differences in absorption of the active substance from both formulations. Diclofenac sodium from formulation 1 was detected in plasma 1 hour after administration, and 15 minutes after administration of the formulation 2. The peak plasma concentrations of diclofenac sodium in both formulations were reached 2 hours after administration. After 24 hours diclofenac sodium was not detected in the plasma of the treated animals in either formulation (Figure 2).

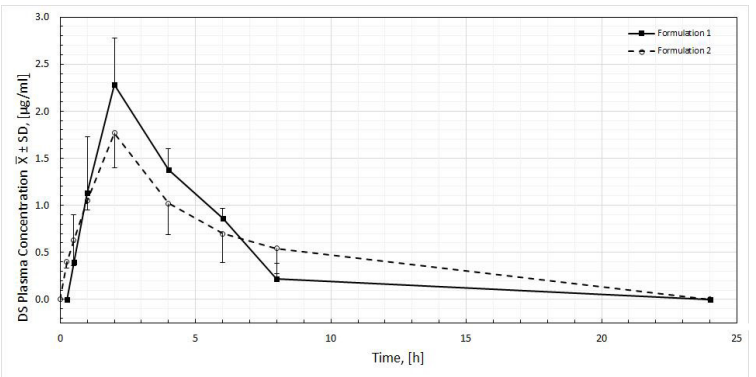

Figure 2. Average plasma concentration value of diclofenac sodium in both formulations in tested animals as the function of time.

Pharmacokinetic parameters were calculated on the basis of noncompartment model due to the elimination of the drug from the body of the treated animals that could be described by the first-order kinetics. Average maximum concentrations (Cmax) after administration of the formulation 1 and 2 tablets were 2.27 and $1.76 \mu \mathrm{g} / \mathrm{ml}$, respectively. Total areas under the curve (AUC0-24) after administration of the drug were 10.80 and $11.40 \mu \mathrm{gh} / \mathrm{ml}$ for formulations 1 and 2, respectively. Elimination halftimes $(\mathrm{T} 1 / 2)$ of diclofenac sodium of the formulation 1 was $3.6 \mathrm{~h}$, while that of the formulation 2 was $5.0 \mathrm{~h}$. Values of pharmacokinetic parameters are shown in the table 3.

Table 3. Pharmacokinetic parameters of both tested formulations of diclofenac sodium film/tablets in rabbits.

\begin{tabular}{|l|c|c|}
\hline Parameter & Formulation 1 & Formulation 2 \\
\hline $\mathrm{Cmax}(\mu \mathrm{g} / \mathrm{ml})$ & $2.27 \pm 0.50$ & $1.76 \pm 0.37$ \\
\hline $\operatorname{Tmax}(\mathrm{h})$ & $2 \pm 0.00$ & $2 \pm 0.00$ \\
\hline $\mathrm{T} 1 / 2(\mathrm{~h})$ & $3.6 \pm 0.28$ & $5.0 \pm 1.42$ \\
\hline AUCO-24( $\left.\mu \mathrm{g}^{*} \mathrm{~h} / \mathrm{ml}\right)$ & $10.80 \pm 2.9$ & $11.94 \pm 4.04$ \\
\hline Disintegration $(\mathrm{sec})$ & Ph. Eur. 2.9.1 & 968 \\
\hline
\end{tabular}

According to ANOVA the differences of pharmacokinetic parameters were not statistically significant. The program calculated p-values under the null hypothesis that all samples (measurement on different rabbits) were given from the same population with the equal average values and the following values were obtained: $\mathrm{p} 1=0.781$, while $\mathrm{p} 2=0.645$. Since both values are far from 0 , it can be concluded that the null hypothesis was confirmed which means that average value from neither sample significantly differs/deviates from other average values of other samples.

\section{Bioequivalence of the tested formulations}

As a base for bioequivalence analysis parameters were determined: AUC0-24, Cmax, Tmax. Bioequivalence criteria is confidence interval of $90 \%$ for relation of average values of pharmacokinetic parameters of both formulations must be in a range between 0.8-1.25. The results of comparison of pharmacokinetic parameters, area under the curve, maximum concentrations and reaching time (Table 4), did not show significant difference.

Table 4. Summary of the obtained comparative pharmacokinetic data for two diclofenac sodium film tablet formulations in rabbits.

\begin{tabular}{|c|c|c|c|c|c|c|}
\hline Formulation & $A \cup C_{0-24}$ & $\begin{array}{l}\mathrm{AUC}_{2} / \\
\mathrm{AUC}_{1}\end{array}$ & Cmax & $\begin{array}{l}C \max _{2} / \\
C \max _{1}\end{array}$ & Tmax & $\begin{array}{c}\operatorname{Tmax}_{2} / \\
\operatorname{Tmax}_{1}\end{array}$ \\
\hline 1. & 10.80 & \multirow{2}{*}{1.10} & 2.27 & \multirow{2}{*}{0.80} & 2 & \multirow{2}{*}{1} \\
\hline 2. & 11.94 & & 1.76 & & 2 & \\
\hline
\end{tabular}

\section{DISCUSSION}

Based on the obtained results and comparison of pharmacokinetic parameters for both formulations a conclusion can be drawn that there is a bioeqivalence of the tested formulations of diclofenac sodium in rabbits, because all the criteria noted earlier were fulfilled, even though the in vitro/ in vivo correlation was not confirmed.

Analysis of the final products showed that film-coated tablets formulation 2 disintegrated faster under the in vitro conditions. However, after only 30 minutes almost whole amount of diclofenac sodium was released from both formulations and there were no significant differences between them. Slower disintegration of the formulation 1 film coated tablets can be related to existence of two layers of polymer coated substances which are gastrosoluble layer with HPMC and enterosolvent layer Eudragit L 30 D 55. Coated substances that contain carboxyl groups are much more resistant to water and steam than polymer with amino groups. That is why it is commonly recommended that these coating substances should be used for tablet cores, if the active substance is moisturesensitive. ${ }^{18}$ Even HPMC does not affect the level of disintegration of film coated tablets; its presence as film material can influence the tablet disintegration rate. ${ }^{19}$ Futhermore, the increase in the amount of magnesium stearate in formulation 1 also leads to slower disintegration of the drug, because of its distinct hydrophobic nature. ${ }^{20}$ Everything mentioned above is in accordance with the results of De Castroet al. (2006) $)^{21}$ and Emara et al. (2014). ${ }^{10}$ This finding confirmed the correlation between the thickness of the film, amount of disintegrator and the level of dissolution, because the tablets with the thicker film and bigger amount of disintegrator showed slower solubility, but un- 
like ours, they presented the in vitro equivalence. Unlike Eudragit coating, which was used in our study, testing the effects of coating material with PVP-K 40 separately and in combination with different types of materials for the coating in different ratio, showed in vitro equivalence with many high level similarities, which is contrary to the results of our study, but also show in vivo equivalence (Igbal et a.1, 2011) .

The value of the obtained similarity factor in conditions invitro $\mathrm{f} 2=23.83$ shows that in vitro equivalence was not confirmed, which is contrary to the results of the studies by Hosny et al. (1998) ${ }^{11}$ and Sheng-Fang Su et al. $(2003)^{12}$ that showed the existence of in vitro equivalence of the tested formulations.

The obtained results of our study of in vitro equivalence were expected due to different modalities of tablet coating, thickness of the coating material and hardness of the tablet core, but related to the in vitro equivalence. It can be concluded that the thickness of the coating material used and the hardness of the tablet core can affect the in vitro equivalence, but those are not the only or conclusive factors, as types and amount of used agent for disintegration of tablet core must be considered.

The results of bioequivalence testing in rabbits showed that diclofenac sodium absorption of the formulation 2 was faster compared to formulation 1 due to the faster disintegration of tablets and appearance of diclofenac sodium in plasma. When passing through the gastrointestinal muculous system , the tablets of the formulation 1 would sustain in the stomach longer because of the presence of the gastrosoluble layer containing hydroxypropyl methylcellulose. After that, they move to lower parts of gastrointestinal system to the intestine where disintegration of soluble enteric coating of film-coated tablets at $\mathrm{pH} 5.5$, by swelling and diffusion of intestinal content into the tablet takes place. Diclofenac sodium diffuses through the created gaps in the tablet and gets absorbed into the blood. The formulation 2 tablets coated with soluble enteric polymer, pass through the stomach unchanged and disintegration starts in the intestine at $\mathrm{pH} 6$ by swelling and diffusion. The swelling of Eudragit L 100 is accomplished apparently faster from Eudragit L $30 \mathrm{D} 55$, but both polymers are part of the group of socalled fast disintegrators with high permeability. The time analysis of reaching maximum peak concentrations in the blood (Figure 2) leads to the conclusion that even though the disintegration of the formulation 2 tablets is faster the absorption rate of diclofenac sodium is slower than of the formulation 1 tablets. The maximum peak concentrations of diclofenac sodium in plasma in both formulations are reached 2 hours after administration of the diclofenac sodium. It points to the higher absorption rate, and slower disintegration rate of the formulation 1 tablets, which is in correlation with testing in vitro. This fact shows that transfer of molecules from formulation 1 is faster through the gastrointestinal membrane cells into the circulation. After 24 hours diclofenac sodium was not detected in the plasma of the tested animals in either formulation. The maximum average concentration values (Cmax) obtained after the administration of the formulation 1 tablets were 2.27 $\mu \mathrm{g} / \mathrm{ml}$, while that of the formulation 2 were $1.76 \mu \mathrm{g} / \mathrm{ml}$. The stated data is in correlation with the tested content of diclofenac sodium in the film-coated tablets. Elimination half-time $(\mathrm{T} 1 / 2)$ of diclofenac sodium from formulation 1 is $3.6 \mathrm{~h}$, while that value from the formulation 2 is 5.0 h. However, for all the stated differences in obtained parameters it can be concluded that they are in the range of biological variations in experiments in vivo. Since the two formulations were tested in each animal (crossover study design) the variations between animals were avoided.

The described model of testing different formulations of an active ingredient in rabbits is apparently interesting for comparisons between in vitro and in vivo data regarding new tablet formulations. When a tablet fomulation is selected for the further testing, including bioequivalence studies in humans, it would be wise firstly to complete the study in rabbits before starting expensive and uncertain bioequivalence studies in humans. The study in rabbits is cheap and relatively rapid, sampling of $1 \mathrm{ml}$ of blood about 10 times in 24 hours and again after about two weeks during the study does not represent a physiological problem for an animal that usually has about $400 \mathrm{ml}$ of blood. The final results on pharmacokinetics of selected formulations can be obtained even within 30 days depending on how fast the tested substance is eliminated from blood and how many formulations shall be tested. It is important to apply the formulations in crossover manner to each animal in order to minimize interindividual variations. When it is found that two tested formulations or one new formulation and one of the reference tablet are bioequivalent in rabbits, it can be predicted with more certainty that those formulation could be bioequivalent in humans. However, if bioequivalence is not obtained in rabbits it cannot be expected that tested formulations would be bioequivalent in humans. In that case tablet formulation shall be returned to laboratory for further development. More importantly, the sponsor should not invest into costly bioequivalence testing in humans as the outcome of such studies can be unfoavourable.

In conclusion, it is not sufficient to conduct evaluations in vitro and based on that assumption at the drugs would also be bioequivalent in in vivo conditions or not, because the effect of biological factors on bioavailability of the drug would be neglected. 


\section{REFERENCES}

1. Popović J, Mikov M, Sabo A, Jakovljević V. Evaluation of statistical power function for various diclofenac bioequivalence trials with different subject numbers. Eur J Drug Metabol Pharmacokinet 2009; 34: 85.

2. Ali H, Shoaib MH, Zafar F, et al. Pharmacokinetic and bioequivalence studies of immediate release diclofenac potassium tablets $(50 \mathrm{mg})$ in healthy volunteers. Pak J Pharm Sci 2016; 29: 1671-79.

3. In-vitro/In-vivo correlation for extended-release oral dosage forms. Stimuli to the revision process. The United States Pharmacopeia Convention Inc, 1988; 4160.

4. PMA's Joint Committee on Bioavailability. The role of dissolution testing in drug quality, bioavailability and bioequivalence testing. Pharm Technol 1985; 9: 62-6.

5. Welling PG. Pharmacokinetics: processes and mathematics. Washington. DC: American Chemical Society, 1986.

6. Selen A. Factors influencing bioavailability and bioequivalence, in pharmaceutical bioequivalence. In: Welling PG, Tse FLS, Dighe SV, eds. Pharmaceutical bioequivalence, drugs and the pharmaceutical science. New York: Marcel Dekker Inc, 1991: 117-48.

7. Center for drug evaluation and research. Guidance for industry: dissolution testing of immediate release solid oral dosage forms. Silver Spring: U.S. Food and Drug Administration, 1997.

8. Basmenji S, Valizadeh H, Zakeri-Milani P. Comparative in vitro dissolution and in vivo bioequivalence of two diclofenac enteric coated formulations. Arzneimittelforschung 2011; 61: 566-70.

9. Iqbal Z, Khan R, Nasir F, Khan JA, Rashid A, Khan A, Khan A. Preparation and in-vitro in-vivo evaluation of sustained release matrix diclofenac sodium tablets using PVP-K90 and natural gums. Pak J Pharm Sci 2011; 24: 43543.

10. Emara LH, Taha NF, El-Ashmawy AA, Raslan HM, Mursi NM. Controlled porosity osmotic pump system for the delivery of diclofenac sodium: in-vitro and in-vivo evaluation. Pharm Dev Technol 2014; 19: 681-91.

11. Hosny EA, El-Mahrouk GM, Gouda MW. Formulation and in vitro and in vivo availability of diclofenac sodium enteric-coated beads. Drug Dev Ind Pharm 1998; 24: 661-6.
12. Su SF, Chou CH, Kung CF, Huang JD. In vitro and In vivo comparison of two diclofenac sodium sustained release oral formulations. Int J Pharma 2003; 260: 39-46.

13. Validation of analitical procedures. Text and methodology Q2(R1). ICH harmonised tripartite guideline. Geneva: The International Council for Harmonisation of Technical Requirements for Pharmaceuticals for Human Use, 2005.

14. Analitical procedures and methods validation. Guidance for Industry. Silver Spring: U.S. Food and Drug Administration, Center for Drug Evaluation and Research (CDER), Center for Biologics Evaluation and Research (CBER), 2015.

15. Reviewer Guidance. Validation of chromatographic methods. U.S. Food and Drug Administration, Center for Drug Evaluation and Research (CDER), 1996.

16. European pharmacopoeia: published in accordance with the Convention on the Elaboration of a European Pharmacopoeia (European Treaty Series no. 50). 8th ed. Strasbourg: Council of Europe, 2016.

17. Westlake WJ. Bioavailability and bioequivalence of pharmaceutical formulations. In: Peace, KE, ed. Biopharmaceutical statistics for drug development. New York: Marcel Dekker, Inc., 1988; 329-52.

18. Lehmann K, Dreher D. Mixtures of aqueous polymethacrylate dispersions for drug coating. Drugs Made in Ger 1988; 31: 101-2.

19. Emami J, Ghassami N, Talari R. A rapid and sensitive modified HPLC method for determination of diclofenac in human plasma and its application in pharmacokinetic studies. DARU Journal of Pharmaceutical Sciences 2007; 15: $132-8$.

20. Shargel L, Yu ABC. Applied biopharmaceutics and pharmacokinetics. 7th edition. New York : McGraw-Hill Education, 2016.

21. De CastroWV, Pires MAS, Oliveira MA, et al. The influence of formulation on the dissolution profile of diclofenac sodium tablets. Drug Dev Ind Pharm 2006; 32: 1103-9. 